\title{
Pola Tekstur Permukaan untuk Klasifikasi Mutu Ubin Teraso Menggunakan GLCM dan KNN
}

\author{
Terazzo Surface Texture for Quality Classification using GLCM and KNN
}

\author{
Doni Briyan Wahyudi ${ }^{* 1}$, Kusrini ${ }^{2}$, Ferry Wahyu Wibowo ${ }^{3}$ \\ 1,2,3 Program Studi S2 Teknik Informatika Universitas Amikom Yogyakarta \\ E-mail: ${ }^{* 1}$ bryant85@gmail.com, ${ }^{2}$ kusrini@amikom.ac.id, ${ }^{3}$ ferry.w@amikom.ac.id
}

\begin{abstract}
Abstrak
Ubin teraso adalah pelapis lantai ataupun tembok yang menggunakan bahan batu marmer, kristal kuarsa, granit, gelas, dan bahkan pelat logam. Industri ubin teraso tetap terjaga meskipun tergolong karya klasik, karena sifatnya yang mewah. Proses pengendalian mutu dilakukan dengan memeriksa tekstur permukaannya. Fitur tekstur dari permukaan ubin teraso bisa diekstraksi melalui pengolahan citra digital, sehingga bisa ditentukan nilai kehalusannya yang menyatakan sebagai produk layak jual atau gagal produksi. Penelitian ini melakukan analisis fitur gray level co-occurence matrix (GLCM) citra permukaan ubin teraso, yaitu angular second moment (ASM), contrast, inverse different moment (IDM), entropy, dan correlation. Nilai varians dan simpangan baku masing-masing fitur tersebut digunakan sebagai indikator kemampuan dan akurasi melakukan klusterisasi data. Algoritma k-nearest neighbor (KNN) digunakan untuk menerima masukan dari masing-masing lima fitur tersebut untuk didapatkan hasil pembelajaran maupun pengenalan dan dibandingkan dengan kondisi sebenarnya. Hasil akhir dari penelitian ini menunjukkan bahwa dari kelima fitur GLCM terdapat empat fitur yang layak digunakan sebagai alat klusterisasi data pada mutu ubin teraso, yaitu ASM, IDM, entropy, dan correlation. Sementara fitur contrast dinyatakan tidak layak sebagai pembeda klasifikasi. Selain itu, pengenalan menggunakan KNN untuk klasifikasi mutu pada ubin teraso menghasilkan akurasi 85\% bagi mutu "layak jual" dan 85\% bagi mutu "gagal produksi".
\end{abstract}

Kata Kunci - GLCM, k-nearest neighbor, ubin teraso, kendali mutu, ekstraksi fitur tekstur

\begin{abstract}
Terrazzo tiles are decorative covering materials for floor and wall consisted of quartz sand, marble, granite, glass, and metal coating. Nowadays, the terrazzo tile industry is maintained despite old fashioned, due to its luxurious nature. The quality control process is carried out by examining the surface texture. Texture features of the terrazzo tile surface can be extracted through digital image processing, so that the fineness value can be determined which states that it is a good product or production defects. This study analyzed calculation of the gray level co-occurrence matrix (GLCM) features from the terrazzo tile surface image data, namely angular second moment (ASM), contrast, inverse different moment (IDM), entropy, and correlation. Variance values and standard deviations of each feature are used as accuracy indicators for data clustering. K-nearest neighbor algorithm (KNN) is used to obtain learning and recognition results and will be compared with actual conditions. The final results indicate that only four features are feasible to be used as data clustering tools, namely ASM, IDM, entropy, and correlation, while the contrast feature is considered inappropriate. In addition, usage of KNN for quality classification on terrazzo tiles produces $85 \%$ accuracy for all quality.
\end{abstract}

Keywords - GLCM, k-nearest neighbor, terrazzo tiles, quality control, texture feature extraction 


\section{PENDAHULUAN}

Salah satu bidang yang belum menerapkan otomatisasi adalah kendali mutu pada jenis permukaan produk ubin teraso. Meskipun lantai bangunan saat ini sudah banyak yang beralih ke ubin porselen yang lebih tipis dan berkilau, namun ubin teraso masih banyak dipakai karena memiliki tampilan lebih elegan, mewah, dan kokoh. Ubin teraso banyak dipakai selain sebagai pelapis lantai juga sebagai pelapis tembok yang terlihat lebih mewah. Selain dari penampakannya, nilai tambah yang didapat ubin teraso adalah karena bahan bakunya yang berupa batu marmer, kristal kuarsa, granit, gelas, dan bahkan pelat logam.

Untuk mendapatkan produk yang berkualitas, ubin teraso mengalami pemolesan sehingga permukaannya memiliki kilap mewah. Setelah dilakukan pemolesan, maka produk akhir tersebut harus dikendalikan kualitasnya dengan melakukan inspeksi pada permukaannya. Hal ini akan sulit dilakukan manusia karena terkadang perbedaan tingkat kekasaran dan mengkilapnya permukaan ubin teraso yang diijinkan sangat kecil.

Fitur tekstur dari permukaan ubin teraso dapat diekstraksi melalui pengolahan citra digital, sehingga bisa ditentukan nilai kekasarannya. Hal ini disebabkan permukaan ubin teraso memiliki pola-pola tertentu sesuai dengan tingkat kekasarannya, yang bagi manusia sulit untuk membedakannya secara cepat.

Pengambilan fitur tekstur permukaan sebagai indikator mutu produk ubin teraso ini dimotivasi oleh penelitian yang dilakukan Widyaningsih pada tahun 2016 yang melakukan identifikasi kematangan buah apel menggunakan gray level co-occurence matrix (GLCM) [1], penelitian yang dilakukan Gunawan pada tahun 2014 yang mengangkat topik tentang identifikasi kualitas kayu untuk kendali mutu berbasis pengolahan citra [2], penelitian oleh Subairi pada tahun 2018 yang melakukan pendeteksian masa ovulasi wanita melalui pola tesktur citra [3], dan penelitian oleh Agmalaro pada 2013 tentang identifikasi tanaman buah tropika berdasarkan tekstur permukaan daun [4].

Aplikasi tekstur dibagi menjadi dua kategori, yaitu pertama adalah untuk kepentingan segmentasi, di mana tekstur dipakai untuk melakukan pemisahan antara satu objek dengan objek lain; kedua adalah untuk klasifikasi tekstur, yang menggunakan fitur-fitur tekstur untuk klasifikasi objek.

Metode statistik akan digunakan pada penelitian ini untuk perhitungan statistika pembentuk fitur, yang berupa gray level co-occurence matrices (GLCM). Metode yang akan digunakan untuk klasifikasi hasil dari nilai GLCM tersebut adalah k-nearest neighborhood (KNN), yang juga telah diaplikasikan pada berbagai bidang. KNN merupakan metode klasifikasi objek dengan menggunakan indikator data pembelajaran yang memiliki jarak terdekat antara objek lain dengan klasifikasi tertentu terhadap objek tersebut. Setiap elemen dari data pembelajaran yang merupakan indikasi fitur dimasukkan ke sumbu dari dimensi jamak. Ruang ini dibagi menjadi bagian-bagian berdasarkan klasifikasi data pembelajaran. Dekat atau jauhnya tetangga biasanya dihitung berdasarkan jarak Euclidean.

Selain penelitian oleh Subairi pada tahun 2018[3], penelitian yang dilakukan Rohman pada 2015 tentang aplikasi KNN untuk prediksi kelulusan mahasiswa[5], penelitian yang dilakukan Imandoust pada 2013 tentang penggunaan KNN untuk prediksi kejadian ekonomi[6], penelitian yang dilakukan oleh Fatoni pada tahun 2017[7], dan penelitian yang dilakukan oleh Kholil pada tahun 2018 tentang penggunaan KNN untuk seleksi penerima beasiswa[8] juga menjadi motivasi untuk menggunakan perbandingan algoritma KNN sebagai metode klasifikasi. Pada penelitian oleh Fatoni tersebut, algoritma KNN digunakan untuk diagnosis penyakit difteri, yang merupakan sistem pakar pengganti ahli yang mampu melakukan klasifikasi berdasarkan diagnosis yang diisi sendiri oleh pengguna[7]. Sedangkan penelitian oleh Kholil menyebutkan bahwa penggunaan KNN juga bisa dilakukan dalam klasifikasi mahasiswa yang layak untuk menjadi penerima beasiswa[8].

Pada penelitian ini akan dilakukan analisis mendalam pada perhitungan lima fitur GLCM dari data citra permukaan ubin teraso, yang meliputi angular second moment (ASM), contrast, inverse different moment (IDM), entropy, dan correlation, yang diambil dari masing-masing 
sudut $0^{\circ}, 45^{\circ}, 90^{\circ}$, dan $135^{\circ}$. Nilai varians dan simpangan baku masing-masing fitur tersebut pada klasifikasi yang sejenis akan digunakan sebagai indikator kemampuan dan akurasi untuk melakukan klusterisasi data. Algoritma KNN akan menerima masukan dari masing-masing lima fitur tersebut untuk didapatkan hasil pembelajaran maupun pengenalan dan dibandingkan dengan kondisi sebenarnya. Hasil yang diharapkan adalah pengenalan dengan akurasi paling akurat untuk masing-masing fitur GLCM maupun penggabungannya.

\section{METODE PENELITIAN}

\subsection{Jenis Penelitian}

Jenis penelitian ini adalah kuantitatif, yang menjadi faktor penting dalam proses penelitian itu sendiri. Teori yang ada akan digunakan untuk menentukan masalah penelitian, menemukan hipotesis, menentukan rancangan sistem, dan menentukan cara pengujian dengan metode untuk melakukan analisis data hasil pengujian. Penelitian dilakukan secara mandiri menggunakan metode eksperimen.

\subsection{Sifat Penelitian}

Penelitian ini memiliki sifat kuantitatif, yaitu harus bisa diukur berdasarkan data, pengamatan, dan argumentasi ilmiah. Kesimpulan yang dibuat bersifat rasional yang didasarkan pada data klasifikasi yang tersedia. Penelitian ini juga didukung oleh pengembangan konsep dan teori yang berupa produk otomatisasi terapan yang bisa berguna bagi masyarakat dan bisa dipertanggungjawabkan secara ilmiah.

\subsection{Pendekatan Penelitian}

Pendekatan pada penelitian ini adalah pendekatan kuantitatif, di mana data yang diambil merupakan data standar klasifikasi mutu produk ubin teraso yang diproduksi. Langkah setelah data didapatkan adalah melakukan analisis dan data tersebut digunakan sebagai pembanding pada kondisi nyata. Hasil pembandingan akan diukur akurasinya sebagai tolok ukur keberhasilan hipotesis yang telah dirumuskan.

\subsection{Metode Pengumpulan Data}

Langkah yang digunakan dalam penelitian ini untuk melakukan pengumpulan data adalah studi literatur, observasi, dan wawancara. Studi literatur digunakan untuk mengumpulkan teori dan konsep tentang metode yang digunakan dalam penelitian ini, baik berupa buku atau hasil penelitian. Penelitian sebelumnya yang digunakan sebagai referensi dikumpulkan dalam bentuk jurnal, proceeding, atau laporan penelitian.

\subsection{Metode Analisis Data}

Pada tahapan penelitian ini akan dilakukan proses analisis dari data yang telah diperoleh sebagai bahan penelitian. Analisis dilakukan untuk melakukan penyederhanaan agar lebih mudah dibaca dan ditafsirkan.

Kelima fitur GLCM yang akan dipakai dan dianalisis kelayakannya untuk menjadi komponen klasifikasi antara lain:

1. Angular Second Moment (ASM), yang merupakan ukuran homogenitas citra, yaitu bagaimana piksel-piksel dalam citra tersebut memiliki persamaan satu sama lain.

2. Contrast, yaitu ukuran keberadaan variasi aras keabuan piksel citra pada sudut tertentu.

3. Inverse Different Moment (IDM), adalah homogenitas, yaitu nilai yang berbanding terbalik dengan ASM. 
4. Entropy, yang menyatakan ukuran ketidakteraturan aras keabuan di dalam citra. Nilainya tinggi jika elemen-elemen GLCM mempunyai nilai yang relatif sama.

5. Correlation, yang merupakan ukuran ketergantungan linier antar nilai aras keabuan dalam citra.

Fitur ASM bisa didapatkan dari GLCM menggunakan Persamaan (1) [9]. Fitur contrast didapatkan melalui Persamaan (2) [10]. Fitur IDM bisa didapatkan menggunakan Persamaan (3) [9]. Fitur entropy didapatkan melalui Persamaan (4) [9]. Terakhir untuk fitur correlation didapatkan dengan menggunakan Persamaan (5) [10].

$$
\begin{aligned}
& A S M=\sum_{i=1}^{L} \sum_{j=1}^{L}(\operatorname{GLCM}(i, j))^{2} \\
& \operatorname{Ctr}=\sum_{n=1}^{L} n^{2} \cdot \sum_{|i-j|=1}^{n} \operatorname{GLCM}(i, j)[10] \\
& I D M=\sum_{i=1}^{L} \sum_{j=1}^{L} \frac{(\operatorname{GLCM}(i, j))^{2}}{1+(i-j)^{2}}[9] \\
& \text { Ent }=-\sum_{i=1}^{L} \sum_{j=1}^{L}(\operatorname{GLCM}(i, j) \cdot \log (\operatorname{GLCM}(i, j))[9] \\
& \operatorname{Crl}=\frac{\sum_{i=1}^{L} \sum_{j=1}^{L} i^{2} \cdot \operatorname{GLCM}(i, j)-\mu_{i}^{\prime} \cdot \mu^{\prime}}{\sigma_{i}^{2} \cdot \sigma_{j}^{2}}[10]
\end{aligned}
$$

\subsection{Alur Penelitian} Gambar 1.

Secara garis besar, penelitian ini memiliki alur yang sistematis seperti ditunjukkan pada

Langkah yang digunakan dalam penelitian ini untuk mengumpulkan data adalah studi literatur, observasi, dan wawancara. Studi literatur digunakan untuk mengumpulkan teori dan konsep tentang metode yang digunakan dalam penelitian ini, baik berupa buku atau hasil penelitian. Penelitian sebelumnya yang digunakan sebagai referensi dikumpulkan dalam bentuk jurnal, proceeding, atau laporan penelitian.

Data yang didapat akan dianalisis untuk menentukan rumusan masalah. Kemudian sistem akan dirancang menggunakan metode-metode yang ada, yaitu GLCM dan KNN. Sistem akan dilatih dan diuji untuk mendapatkan tes kelayakan fitur pada GLCM dengan rincian varians dan simpangan baku setiap nilainya, kemudian hasil uji klasifikasi akan diuji menggunakan confusion matrix. 
Citec Journal, Vol. 5, No. 1, November 2017 - Januari 2018

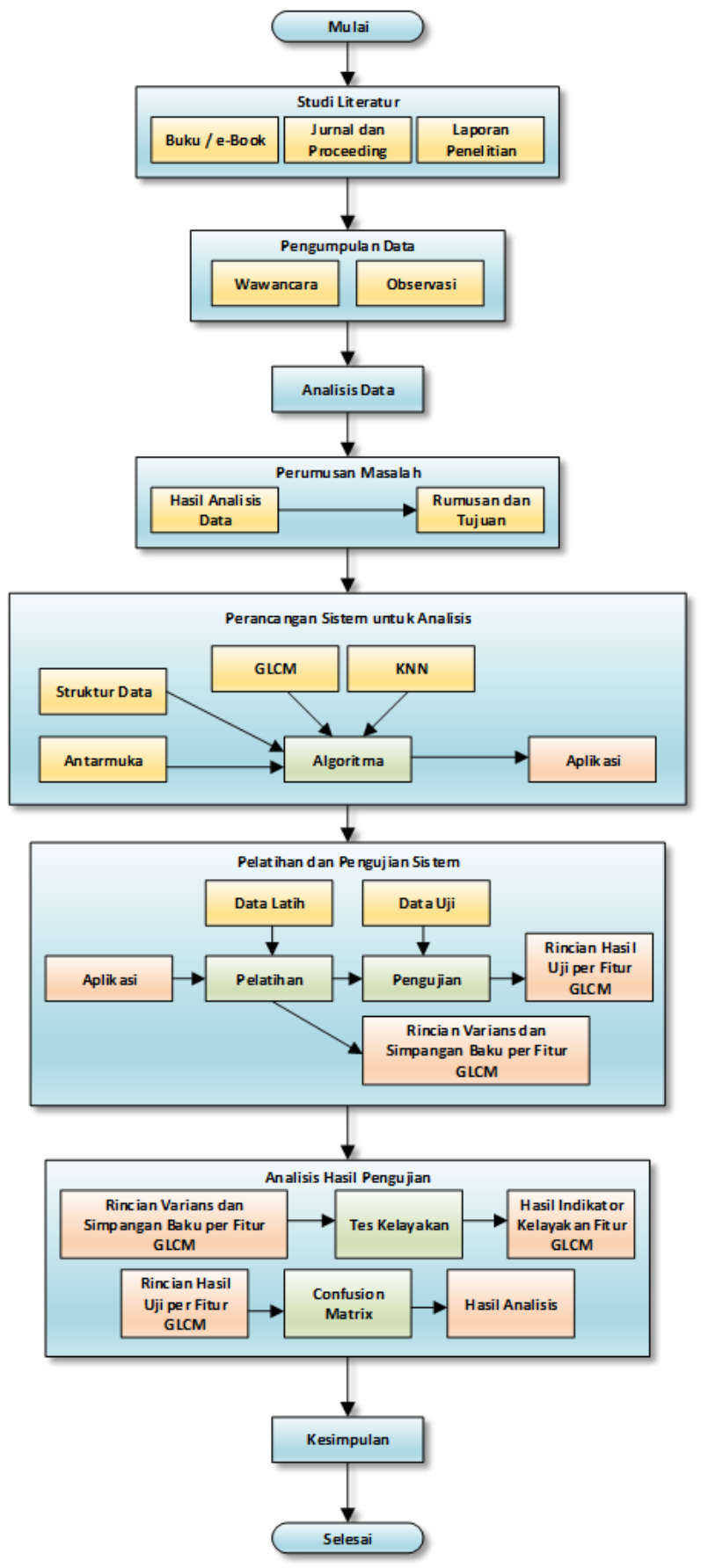

Gambar 1. Alur Penelitian

\section{HASIL DAN PEMBAHASAN}

\subsection{Kelayakan Fitur GLCM}

Data yang didapatkan adalah citra ubin teraso dari perusahaan sebanyak 30 citra dengan dua klasifikasi mutu, yaitu "layak jual” sebagai klasifikasi pertama dan "gagal produksi” sebagai klasifikasi kedua. Terdapat 15 citra klasifikasi pertama dan 15 citra klasifikasi kedua. Dari masing-masing klasifikasi diambil 5 citra secara acak untuk pelatihan dan 10 sisanya untuk pengujian. 

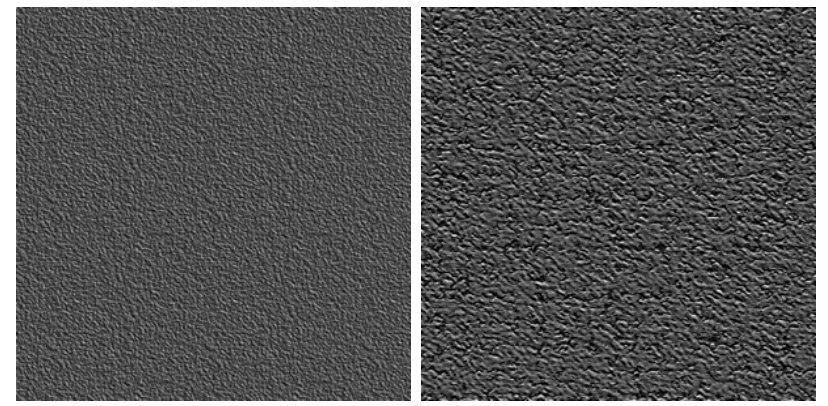

Gambar 2. Contoh citra keabuan permukaan ubin teraso klasifikasi “layak jual” (kiri) dibandingkan dengan klasifikasi "gagal produksi” (kanan).

Citra yang akan dipakai untuk pelatihan dan pengujian merupakan citra keabuan yang diambil dari proses foto permukaan ubin teraso dengan ukuran $512 \times 512$ piksel, pencahayaan yang konsisten, dan menggunakan pembesaran 50 kali. Karena menggunakan mikroskop yang terhubung dengan USB port, maka pencahayaan pada citra diambil dari arah depan.

Contoh pada Gambar 2 menyatakan perbedaan antara kedua klasifikasi tersebut. Pada proses pelatihan, didapatkan hasil yang bervariasi pada rata-rata nilai dari masing-masing fitur GLCM. Sesuai dengan skenario, sebanyak 5 citra dari klasifikasi pertama dan 5 citra dari klasifikasi kedua dilatihkan ke sistem. Tabel 1 menunjukkan hasil nilai fitur GLCM yang telah didapatkan untuk klasifikasi pertama (layak jual).

Tabel 1. Hasil Nilai Fitur GLCM untuk Klasifikasi “Layak Jual”

\begin{tabular}{|c|c|c|c|c|c|}
\hline & ASM & Contrast & IDM & Entropy & Correlation \\
\hline Citra 1 & $2.3340 \mathrm{E}-01$ & $1.5430 \mathrm{E}+00$ & $2.4423 \mathrm{E}+00$ & $2.3000 \mathrm{E}-03$ & $5.4342 \mathrm{E}-02$ \\
\hline Citra 2 & $7.3645 \mathrm{E}-01$ & $9.8349 \mathrm{E}-01$ & $3.1122 \mathrm{E}+00$ & $6.8717 \mathrm{E}-02$ & $6.4721 \mathrm{E}-02$ \\
\hline Citra 3 & $2.3111 \mathrm{E}-01$ & $7.2398 \mathrm{E}-01$ & $2.5630 \mathrm{E}+00$ & $8.1230 \mathrm{E}-02$ & $4.5433 \mathrm{E}-02$ \\
\hline Citra 4 & $4.3823 \mathrm{E}-01$ & $1.2130 \mathrm{E}+00$ & $3.1112 \mathrm{E}+00$ & $4.7843 \mathrm{E}-04$ & $7.2424 \mathrm{E}-02$ \\
\hline Citra 5 & $9.1233 \mathrm{E}-01$ & $1.7730 \mathrm{E}+00$ & $4.1231 \mathrm{E}+00$ & $2.3714 \mathrm{E}-02$ & $5.3710 \mathrm{E}-02$ \\
\hline Nilai Rata-rata & $5.1030 \mathrm{E}-01$ & $1.2473 \mathrm{E}+00$ & $3.0704 \mathrm{E}+00$ & $3.5288 \mathrm{E}-02$ & $5.8126 \mathrm{E}-02$ \\
\hline Varians & $7.4517 \mathrm{E}-02$ & $1.4169 \mathrm{E}-01$ & $3.5272 \mathrm{E}-01$ & $1.1324 \mathrm{E}-03$ & $8.8574 \mathrm{E}-05$ \\
\hline Simpangan Baku & $2.7298 \mathrm{E}-01$ & $3.7641 \mathrm{E}-01$ & $5.9391 \mathrm{E}-01$ & $3.3651 \mathrm{E}-02$ & $9.4114 \mathrm{E}-03$ \\
\hline
\end{tabular}

Tabel 2 menunjukkan hasil nilai fitur GLCM yang telah didapatkan untuk klasifikasi kedua (gagal produksi).

Tabel 3. Perbedaan Nilai Fitur GLCM untuk Kedua Klasifikasi dan Indikator Overlap Data

\begin{tabular}{|c|c|c|c|c|c|c|}
\hline Klasifikasi & & ASM & Contrast & IDM & Entropy & Correlation \\
\hline \multirow{4}{*}{ Pertama } & Nilai Rata-rata & $5.1030 \mathrm{E}-01$ & $1.2473 \mathrm{E}+00$ & $3.0704 \mathrm{E}+00$ & $3.5288 \mathrm{E}-02$ & $5.8126 \mathrm{E}-02$ \\
\cline { 2 - 7 } & Varians & $7.4517 \mathrm{E}-02$ & $1.4169 \mathrm{E}-01$ & $3.5272 \mathrm{E}-01$ & $1.1324 \mathrm{E}-03$ & $8.8574 \mathrm{E}-05$ \\
\cline { 2 - 7 } & Simpangan Baku & $2.7298 \mathrm{E}-01$ & $3.7641 \mathrm{E}-01$ & $5.9391 \mathrm{E}-01$ & $3.3651 \mathrm{E}-02$ & $9.4114 \mathrm{E}-03$ \\
\hline \multirow{3}{*}{ Kedua } & Nilai Rata-rata & $8.0230 \mathrm{E}-01$ & $3.8393 \mathrm{E}+00$ & $1.7150 \mathrm{E}+01$ & $1.1873 \mathrm{E}+00$ & $1.5381 \mathrm{E}+00$ \\
\cline { 2 - 7 } & Varians & $6.7910 \mathrm{E}-02$ & $1.7052 \mathrm{E}+01$ & $6.3553 \mathrm{E}+00$ & $5.5813 \mathrm{E}-02$ & $1.5600 \mathrm{E}-01$ \\
\cline { 2 - 7 } & Simpangan Baku & $2.6060 \mathrm{E}-01$ & $4.1295 \mathrm{E}+00$ & $2.5210 \mathrm{E}+00$ & $2.3625 \mathrm{E}-01$ & $3.9496 \mathrm{E}-01$ \\
\hline \multicolumn{2}{|c|}{ Jarak Rata-Rata } & $2.9200 \mathrm{E}-01$ & $2.5920 \mathrm{E}+00$ & $1.4080 \mathrm{E}+01$ & $1.1520 \mathrm{E}+00$ & $1.4800 \mathrm{E}+00$ \\
\hline Overlap Data Pertama-Kedua & $-1.9021 \mathrm{E}-02$ & $-2.2156 \mathrm{E}+00$ & $-1.3486 \mathrm{E}+01$ & $-1.1183 \mathrm{E}+00$ & $-1.4706 \mathrm{E}+00$ \\
\hline \multicolumn{2}{|c|}{ Overlap Data Kedua-Pertama } & $-3.1404 \mathrm{E}-02$ & $1.5375 \mathrm{E}+00$ & $-1.1559 \mathrm{E}+01$ & $-9.1575 \mathrm{E}-01$ & $-1.0850 \mathrm{E}+00$ \\
\hline
\end{tabular}

Dari tabel tersebut, didapatkan bahwa untuk data yang mengalami overlap adalah fitur contrast. Nilai positif dari overlap mengindikasikan bahwa terjadi perpotongan data, khususnya yang dimiliki oleh data dari klasifikasi kedua, yang mengakibatkan fitur contrast tidak layak 
Citec Journal, Vol. 5, No. 1, November 2017 - Januari 2018

ISSN: 2460-4259

digunakan sebagai pembeda klasifikasi. Sedangkan untuk fitur lainnya didapatkan nilai negatif yang menandakan bahwa data nilai antara kedua klasifikasi cukup terkelompokkan sehingga masih layak untuk menjadi pembeda dalam proses klasifikasi.

\subsection{Akurasi Klasifikasi KNN}

Pengujian KNN dilakukan dengan cara menyiapkan data pelatihan sebanyak 30 citra, yang meliputi 15 citra untuk klasifikasi "layak jual" dan 15 citra untuk klasifikasi "gagal produksi”. Seperti yang telah dilakukan pada uji kelayakan fitur GLCM, data sebanyak masingmasing 5 citra tersebut dilatihkan. Namun pada pengujian akurasi KNN kali ini, dilakukan juga pengenalan dari masing-masing 10 citra dari setiap klasifikasi. Confusion matrix yang terbentuk akan diekstrak guna mendapatkan salah satu parameter keluaran, yaitu akurasi.

Pada Tabel 4 ditunjukkan hasil deteksi klasifikasi pada 10 citra uji "Layak Jual", sementara pada Tabel 5 ditunjukkan hasil deteksi klasifikasi pada 10 citra uji "Gagal Produksi”.

Tabel 4. Hasil Uji pada Klasifikasi “Layak Jual”

\begin{tabular}{|c|c|c|}
\hline \multirow{2}{*}{ Nama Citra } & \multicolumn{2}{|c|}{ Terdeteksi Sebagai } \\
\cline { 2 - 3 } & Layak Jual & Gagal Produksi \\
\hline LJ06.jpg & YA & TIDAK \\
\hline LJ07.jpg & YA & TIDAK \\
\hline LJ08.jpg & YA & TIDAK \\
\hline LJ09.jpg & YA & TIDAK \\
\hline LJ10.jpg & YA & TIDAK \\
\hline LJ11.jpg & TIDAK & YA \\
\hline LJ12.jpg & YA & TIDAK \\
\hline LJ13.jpg & YA & TIDAK \\
\hline LJ14.jpg & TIDAK & YA \\
\hline LJ15.jpg & YA & TIDAK \\
\hline Jumlah & 8 & 2 \\
\hline
\end{tabular}

Tabel 5. Hasil Uji pada Klasifikasi “Gagal Produksi”

\begin{tabular}{|c|c|c|}
\hline \multirow{2}{*}{ Nama Citra } & \multicolumn{2}{|c|}{ Terdeteksi Sebagai } \\
\cline { 2 - 3 } & Layak Jual & Gagal Produksi \\
\hline GP06.jpg & YA & TIDAK \\
\hline GP07.jpg & TIDAK & YA \\
\hline GP08.jpg & TIDAK & YA \\
\hline GP09.jpg & TIDAK & YA \\
\hline GP10.jpg & TIDAK & YA \\
\hline GP11.jpg & TIDAK & YA \\
\hline GP12.jpg & TIDAK & YA \\
\hline GP13.jpg & TIDAK & YA \\
\hline GP14.jpg & TIDAK & YA \\
\hline GP15.jpg & TIDAK & YA \\
\hline Jumlah & 1 & 9 \\
\hline
\end{tabular}

Dari hasil uji, didapatkan 8 data yang berhasil diidentifikasi sesuai dengan aktualnya pada klasifikasi pertama. Sedangkan pada klasifikasi kedua, terdapat 9 data yang berhasil diidentifikasi sesuai dengan aktualnya. Confusion matrix yang terbentuk pada klasifikasi pertama ditunjukkan pada Tabel 6. 
Tabel 6. Confusion Matrix yang Terjadi pada Klasifikasi “Layak Jual”

\begin{tabular}{|c|c|c|c|}
\cline { 3 - 4 } \multicolumn{2}{c|}{} & \multicolumn{2}{c|}{ Klasifikasi Aktual } \\
\cline { 3 - 4 } \multicolumn{2}{c|}{} & Layak Jual & Non Layak Jual \\
\hline \multirow{2}{*}{ Hasil Deteksi } & Layak Jual & 8 & 1 \\
\cline { 2 - 4 } & Non Layak Jual & 2 & 9 \\
\hline
\end{tabular}

Klasifikasi pertama mendapatkan nilai true positive sebesar 8 , false negative sebesar 2, false positive sebesar 1 , dan true negative sebesar 9. Tingkat akurasi pada pengenalan klasifikasi "Layak Jual” ini ditunjukkan seperti pada Persamaan (6).

$$
\text { Acc }(\text { LayakJual })=\frac{T P+T N}{P+N}=\frac{8+9}{20}=85 \%
$$

Tabel 7. Confusion Matrix yang Terjadi pada Klasifikasi “Gagal Produksi”

\begin{tabular}{|c|c|c|c|}
\cline { 3 - 4 } \multicolumn{2}{c|}{} & \multicolumn{2}{c|}{ Klasifikasi Aktual } \\
\cline { 3 - 4 } \multicolumn{2}{c|}{} & Gagal Produksi & Non Gagal Produksi \\
\hline \multirow{2}{*}{ Hasil Deteksi } & Gagal Produksi & 9 & 2 \\
\cline { 2 - 4 } & Non Gagal Produksi & 1 & 8 \\
\hline
\end{tabular}

Tabel 7 menunjukkan confusion matrix yang terbentuk pada klasifikasi kedua. Klasifikasi kedua mendapatkan nilai true positive sebesar 9, false negative sebesar 1, false positive sebesar 2, dan true negative sebesar 8. Tingkat akurasi pada pengenalan klasifikasi "Gagal Produksi” ini ditunjukkan seperti pada Persamaan (7).

$$
\text { Acc }(\text { GagalProduksi })=\frac{T P+T N}{P+N}=\frac{9+8}{20}=85 \%
$$

Jadi sesuai dengan confusion matrix maka didapatkan hasil akhir akurasi pengenalan pada klasifikasi "Layak Jual” adalah 85\%, seperti halnya akurasi pengenalan pada klasifikasi "Gagal Produksi” sebesar 85\%.

Jika dibandingkan dengan hasil penelitian sebelumnya, maka penelitian ini mampu melakukan analisis pada tingkat kelayakan fitur GLCM sebelum dipakai sebagai pembeda klasifikasi menggunakan metode pembelajaran mesin. Penelitian oleh Widyaningsih [1], Subairi [3], dan Bino Sebastian V. [11] membahas tentang penggunaan fitur GLCM sebagai alat klasifikasi namun tidak melakukan analisis pada kelayakannya. Penelitian oleh Zulpe [9] dan Girisha B. [12] melakukan analisis tersebut namun tidak diterapkan ke metode pembelajaran mesin.

\section{KESIMPULAN}

Kesimpulan yang bisa ditarik dari penelitian ini adalah:

1. Penggunaan fitur GLCM pada pengenalan klasifikasi mutu ubin teraso berdasarkan tekstur permukaannya layak digunakan menggunakan ASM, IDM, entropy, dan correlation. Penggunaan fitur contrast menunjukkan overlap data yang mengakibatkan tidak layak untuk dipakai sebagai pembeda klasifikasi.

2. Pengenalan klasifikasi menggunakan KNN berdasarkan fitur tekstur permukaan ubin teraso memberikan nilai akurasi untuk "Layak Jual” sebesar 85\% dan untuk "Gagal Produksi" sebesar $85 \%$. 


\section{SARAN}

Penelitian berikutnya diharapkan dapat memberikan lebih banyak fitur GLCM untuk melakukan klasifikasi mutu ubin teraso sehingga didapatkan akurasi yang lebih tinggi. Selain itu diharapkan pula pada penelitian berikutnya akan ada variabel generalisasi yang mampu secara adaptif menentukan pemetaan nilai pembelajaran sehingga dapat digunakan untuk kendali mutu berbagai macam produk selain ubin teraso.

\section{DAFTAR PUSTAKA}

[1] Widyaningsih, M., 2016, Identifikasi Kematangan Buah Apel dengan Gray Level Cooccurence Matrix (GLCM), Jurnal Saintekom, Vol. 6, No. 1, Hal 71-88.

[2] Gunawan, I., Halomoan, J., Atmaja, R. D., 2014, Perancangan Sistem Identifikasi Kualitas Kayu untuk Quality Control Berbasis Pengolahan Citra Digital, Jurnal EPROC, Vol. 2, No. 1, Hal 1-8.

[3] Subairi, Rahmadwati, Yudaningtyas, E., 2018, Implementasi Metode k-Nearest Neighbor pada Pengenalan Pola Tekstur Citra Saliva untuk Deteksi Ovulasi, EECCIS, Vol. 12, No. 1, Hal 9-14.

[4] Agmalaro M. A., Kustiyo, A., Akbar, A. R., 2013, Identifikasi Tanaman Buah Tropika Berdasarkan Tekstur Permukaan Daun Menggunakan Jaringan Syaraf Tiruan, Jurnal Ilmu Komputer Agri-Informatika, Vol. 2, No. 2, Hal 73-82.

[5] Rohman, A., 2015, Model Algoritma K-Nearest Neighbor (KNN) untuk Prediksi Kelulusan Mahasiswa, Jurnal Neo Teknika, Vol. 1, No. 1, Hal. 1-9

[6] Imandoust, S. B., Bolandraftar, M., 2013, Application of K-Nearest Neighbor (KNN) Approach for Predicting Economic Events: Theoretical Background, Journal of Engineering Research and Applications, Vol. 5, No. 5, Hal 605-610.

[7] Fatoni, C. S., Noviandha, F. D., 2017, Case Based Reasoning Diagnosis Penyakit Difteri dengan Algoritma K-Nearest Neighbor, Citec Journal, Vol. 4, No. 3, Hal 220-232.

[8] Kholil, M., Kusrini, Henderi, 2018, Penerapan Metode K Nearest Neighbord dalam Proses Seleksi Penerima Beasiswa, Seminar Nasional Sistem Informasi dan Teknologi Informasi (SENSITEK), Pontianak. 12 Juli 2018.

[9] Zulpe, N., Pawar, V., 2012, GLCM Textural Features for Brain Tumor Classification, IJCSI, Vol. 9, No. 3, Hal 354-359.

[10] Azim, G. A., 2015, Identification of Textile Defects Based on GLCM and Neural Networks, Journal of Computer and Communications, Vol. 3 No. 12, Hal 1-8.

[11] B. S. V., Unnikrishnan, A., Balakrishnan, K., 2012, Gray Level Co-occurrence Matrices: Generalisation and Some New Features, IJCSEIT, Vol. 2, No. 2, Hal 151-157.

[12] Girisha, A. B., Chandrashekhar, M. C., Kurian., M. Z., 2013, Texture Feature Extraction of Video Frames using GLCM, IJETT, Vol. 4, No. 6, Hal 2718-2721.

[13] Sharma, K., Priyanka, Kalsh, A., Saini, K., 2015, GLCM and its Features, IJARECE, Vol. 4, No. 8, Hal 2180-2182. 